\title{
CENTRALIZATION OF PROCUREMENT - ESSENCE AND CURRENT TRENDS
}

\author{
JOANNA DROBIAZGIEWICZ \\ University of Szczecin, Faculty of Management and Economics of Services, POLAND \\ e-mail: joanna.drobiazgiewicz@wzieu.pl
}

\begin{tabular}{l|l} 
RECEIVED & 6 November 2018 \\
ACCEPTED & 3 December 2018 \\
JEL & \\
CLASSIFICATION & L20, M21
\end{tabular}

KEYWORDS purchasing, procurement, centralization of procurement

ABSTRACT The aim of the article is to evaluation of the idea centralizing procurement, its advantages and disadvantages and to indicate practical examples of the application of this strategy in the conditions of development of modern ICT technologies. At the beginning of the article the basic definitions are given: purchasing, procurement and sourcing, to contrast them. Next, the characteristics of the centralization of procurement were indicated by comparing it with decentralization. This part of the work also defines the advantages and disadvantages of procurement centralization. The next part of the article presents practical examples of the application of this strategy both in enterprises and in public administration. The conclusions were formulated at the final part of the article. The paper uses the methods of literature review, analysis, synthesis and case study. Article refers to studies aimed at assessing the validity of the application of the centralization of procurement in enterprises with many departments using modern ICT. The use of this form of purchasing organization brings positive results, as the analyzed examples of Orlen Capital Group or Gaz-System shown.

\section{Introduction}

Nowadays enterprises wanting to gain a competitive advantage and to maximize values in the whole supply chain pay special attention to the appropriate management of purchases. Choosing the right purchasing strategy is not an easy choice. Before a company decides whether to implement centralized or decentralized procurement, the advantages and disadvantages of each model should be analyzed. 


\section{The essence of procurement - literature overview}

Procurement is defined as the whole process of acquiring goods, works and services for the production and operation of an organization from external suppliers (Lysons, Farrington, 2012, pp. 6-8). Most terminologies used in procurement are usually unclear and sometimes used interchangeably. Therefore, it is important to recognize the different terms which are mistaken with procurement.

"Procurement is a wider term than purchasing" and consists of both strategic supplier management and operational purchasing (Lysons, Farrington, 2012, pp. 6-8). Importantly, and distinct from "purchasing", procurement involves the activities involved in establishing fundamental requirements, sourcing activities such as market research and vendor evaluation and negotiation of contracts.

Purchasing can also be defined as a functional a formal entity on the organizational chart as well as a functional activity (buying goods and services). The purchasing department performs many activities to ensure it delivers maximum value to the organization and include supplier identification and selection, buying, negotiation and contracting, supply market research, supplier measurement and improvement, purchasing systems development (Monczka, Handfield, Giuniperro, Patterson, 2008, p. 8). It can be determined that purchasing is one of procurement functions and includes processes of an operational nature. Usually, purchasing refers to the actual buying (Waters, 2003, p. 228).

The purchased goods can generally be grouped into the following categories (Van Weele, 2005, pp. 19-20):

- raw materials,

- supplementary materials; materials that are not absorbed physically in the end product,

- semi-manufactured products,

- components; manufactured goods that will not undergo additional changes, but which will be incorporated with other components,

- finished products; all products which are purchased to be sold,

- investment goods or capital equipment,

- maintenance, repair and operating materials (MRO items); materials, which are necessary for keeping the organization running in general and for the support activities in particular,

- services.

Procurement has a higher status than purchasing and is associated with a longer and wider aspect of operation.

Another term relating to procurement is sourcing. Sourcing is an extended function of procurement because it is a strategic concept. Sourcing consists of the analysis of internal demand for the entire commodity category within an organization. Sourcing is essentially is a cross-function al process, aimed at managing, developing and integrating with the supplier capabilities to achieve a competitive advantage (Monczka, Handfield, Giuniperro, Patterson, 2008, p. 8).While Lockström defines sourcing as: "the process of searching, selecting and managing suppliers as a means for securing a continuous supply of factor inputs for the value creation mechanism" (Lockström, 2007, pp. 9-10).

\section{Characteristics of centralization of procurement}

Proper purchase management is one of the most difficult challenges currently facing businesses. This issue is particularly important in the case of enterprises that are developing and their structure is becoming more and more developed. To ensure the efficiency and effectiveness of procurement, appropriate action should be taken. 
Good practices in procurement related to current trends in business management are (Kardasz, 2008, pp. 97-99; Ocicka, 2017, pp. 335-336):

a) centralization of purchasing functions - companies have a central purchasing department reporting directly to the management;

b) support of the purchase process with procedures and appropriate tools supporting the automation of purchase processes, including mainly IT systems;

c) creating purchase strategies for individual assortment groups;

d) standardization of the assortment, the use of catalogs that minimize the risk of accidental purchases;

e) optimization of the supplier base, including suppliers in cost reduction projects, basing relations with the supplier on framework agreements; involvement of individual departments in this process;

f) globalization of purchases - access to cheaper sources of supply, as well as searching for sources of new technologies and innovative products or willingness to reduce the risk resulting from the monopolistic position of the supplier on the domestic market;

g) implementation of the supplier evaluation system.

Although the application of the principle of economies of scale in making purchases is not a new phenomenon, it takes on a completely different, more modern and more effective form. A special role in the improvement of strategic procurement management is attributed to the centralization of purchases supported by appropriate ICT tools.

The characteristics of the centralization of procurement functions are (Borowiecki, 2008, pp. 2-6):

- consolidation of demand enabling negotiation of favorable terms of purchase,

- the possibility of direct communication with suppliers at the strategic level,

- effective planning of needs,

- unified terms of cooperation with suppliers of various company branches,

- less flexibility of operation,

- more bureaucracy, more formal requirements,

- standardization of purchased goods.

In practice, this means that all shopping functions fall within the scope of one centralized procurement organization, and do not have different functions distributed throughout the entire company. Companies choose a centralized procurement operation because they enable greater efficiency and better control of the shopping function. This makes it easier to maintain policies and procedures that promote a more effective purchasing process.

However, it should be remembered that the purchase costs are not only the direct costs, i.e. the purchase price. The purchase costs are also indirect costs, which often outweigh the most visible ones. These include production costs, goods handling costs, storage costs, capital costs, supply costs, administration costs and development costs (Gadde, Håkansson, Persson, 2010, pp. 7-21). The opposite concept to centralized procurement is decentralized procurement. The comparative overview of centralized and decentralized procurement of are shown in Table 1.

The main advantages of the central purchasing system are:

- lower prices and greater opportunities to get discounts from suppliers thanks to more purchases,

- larger parts of delivery can reduce delivery costs,

- centralized purchase documentation ensures greater transparency of purchasing decisions,

- better communication between the company and its suppliers,

- better inventory management. 
Table 1. Comparative overview of centralized and decentralized procurement

\begin{tabular}{|c|c|c|}
\hline & Centralized procurement & Decentralized procurement \\
\hline Negotiate purchase prices & $\begin{array}{l}\text { - consolidation of demand enabling negotiation } \\
\text { of favorable terms of purchase, } \\
\text { - larger deliveries can reduce delivery charges }\end{array}$ & - small possibilities to negotiate purchase prices \\
\hline Relationships with suppliers & $\begin{array}{l}\text { - unified terms of cooperation with suppliers of various } \\
\text { company branches } \\
\text { - the possibility of direct communication with suppliers at } \\
\text { the strategic level }\end{array}$ & $\begin{array}{l}\text { - lack of unified terms of cooperation with suppliers } \\
\text { between company branches }\end{array}$ \\
\hline $\begin{array}{l}\text { Documentation \& visibility } \\
\text { into purchasing decisions }\end{array}$ & $\begin{array}{l}\text { - a centralized location for all purchasing documentation } \\
\text { provides greater visibility into purchasing decisions } \\
\text { - more bureaucracy, more formal requirements }\end{array}$ & $\begin{array}{l}\text { - less visibility into purchasing decisions, } \\
\text { - less bureaucracy, less formal requirements }\end{array}$ \\
\hline Standardization & - standardization of purchased goods & - lack of standardization of purchased goods \\
\hline $\begin{array}{l}\text { Response to the company's } \\
\text { needs }\end{array}$ & $\begin{array}{l}\text { - less flexibility of operation } \\
\text { - better inventory management from the department's } \\
\text { point of view }\end{array}$ & - faster response to the company's needs \\
\hline Focus on units needs & - less focus on units needs & - focus on unit needs \\
\hline Management of inventories & $\begin{array}{l}\text { - better management of inventories in the dimension of the } \\
\text { enterprise as a whole }\end{array}$ & $\begin{array}{l}\text { - better inventory management from the department's } \\
\text { point of view }\end{array}$ \\
\hline $\begin{array}{l}\text { Acquisition of goods and } \\
\text { analyzing markets }\end{array}$ & $\begin{array}{l}\text { - higher competences in the field of analyzing markets and } \\
\text { acquisition of goods }\end{array}$ & $\begin{array}{l}\text { - lower competences in the field of analyzing markets } \\
\text { and acquisition of goods }\end{array}$ \\
\hline Connection with end users & - distant & - shortened \\
\hline $\begin{array}{l}\text { Focus on operational and } \\
\text { strategic activities }\end{array}$ & - more strategic focus for resource plan and research & $\begin{array}{l}\text { - more focus on operational activities (rather than } \\
\text { strategic) }\end{array}$ \\
\hline Transparency of costs & - - better visibility over spending cost & - - hide purchasing cost \\
\hline
\end{tabular}

Source: own elaboration based on: Borowiecki (2008), pp. 2-6; Van Weele (2005), pp. 229-232; Lysons (2004), pp.70-71; Jonsson, Rudberg, Holmberg (2013), pp. 337-350; Rutkowski (2013), pp. 39-41).

The disadvantages of the centralized purchasing system include, among others, weaker cooperation between the company's departments and suppliers, often extending the delivery time to the consumer of intermediate goods and low flexibility of supply. Centralization of purchases also means less possibilities of cooperation with local suppliers.

Other than the central purchasing structure is a decentralized and hybrid structure, which is a combination of the two previous ones (Borowiecki, 2008, pp. 2-6). Regardless of its structure, the supply function should provide the company with value, contribute to its success and where it is possible to provide sources of competitive advantage.

\section{Examples of centralization of purchases in the era of modern ICT tools}

An example of centralization of procurement is the implementation of the CONNECT Purchase Platform in the Orlen Capital Group, which is an international capital group from the fuel and energy industry. It covers the entire sourcing process, from handling inquiries, through the implementation of procurement procedures, to conducting electronic auctions, as one of the available methods of negotiation. Offers, only in electronic form, are submitted by potential suppliers after logging into the platform. The only condition is to register the company in advance and select the right shopping categories. The CONNECT Purchase Platform has been equipped with a free, automated system of notification of purchase procedures, which guarantees all suppliers regular and equal access to information on the tender process conducted (Orlen, 2018). 
Another example of centralization of procurement are the practices of the Gas Transmission Operator GAZ-SYSTEM. Its key task is to transport gaseous fuels through the transmission network throughout the country, in order to deliver them to distribution networks and end consumers connected to the transmission system. The company introduces a lot of new solutions oriented towards the standardization of the purchasing process. One of them is the centralization of purchases of the selected assortment. The key assumptions of the purchase centralization process are (Gaz-System, 2018):

- a unified assortment,

- identical rules for the execution of orders for all branches (72 procurement categories covered by central supply),

- one contract for different places of delivery, with a uniform acceptance procedure,

- bigger orders, making use of the scale effect,

- similar or identical contract templates,

- communication with suppliers by electronic means, the use of an electronic platform.

Centralization of procurement is also used by state offices. An example is the City of Warsaw, which has been using electronic auctions for several years. Large cities are increasingly thinking about the centralization of purchases, which would include not only the office itself, but also all subordinate units. Sometimes municipal companies in a given city can be even several dozen. In the absence of centralization of purchases, each individual chooses suppliers. The key element of the centralized shopping system is not the auction module, but the functionality that facilitates the bidding process. The functionality of this module includes preparation of the Specification of Essential Terms of the Contract - with information about any changes made therein, the possibility of downloading tender documentation and negotiations with suppliers or electronic voting of the tender committee. In such a system, each stage of the tender is also registered, in which not always, as in electronic auctions, the price counts. In each proceeding, you can choose any criteria for supplier evaluation (Jadczak, 2011).

\section{Conclusions}

One of the actions that should be taken by enterprises and state office is the introduction of coherent purchasing strategies. In order to achieve significant savings, the enterprise must adopt various strategies of using economies of scale and synergy effects. It is necessary to constantly analyze and control the expenses incurred, which is connected with ensuring the transparency of decisions in this respect, appropriate communication and organization of the purchase process. One of the ways to achieve these goals, especially in complex organizations is the introduction of centralization of procurement supported by electronic tools.

However, the centralization of purchases is not always justified. Sometimes it is only introduced to a certain extent or in relation to certain assortment groups. (Van Weele, 2014, p. 273). According to Kraljic, the product group for which purchasing decisions should be made at the central level are: strategic items and bottleneck items (Kraljic, 1983, pp. 109-117). It is not always possible to standardize all good in a given assortment group. Another problem may be the dependence on a small group of suppliers whose bargaining power is growing (Paranikas, Whiteford, Tevelson, Belz, 2015, pp. 90-96). 


\section{References}

Borowiecki, M. (2008). Organizacje zakupowe w firmach wielooddziałowych. Gospodarka Materiałowa i Logistyka, 12, 2-6.

Gadde, L.E., Håkansson, H., Persson, G. (2010). Supply Network Strategies. London: John Wiley \& Sons.

Gaz-System (2018). Retrieved from: www.gazsystem.pl.

Jadczak, A. (2011). Centralizacja zakupów. Computerworld. Retrieved from: https://www.computerworld.pl/news/Centralizacjazakupow,376684.html.

Jonsson, P., Rudberg, M., Holmberg, S. (2013). Centralised supply chain planning at IKEA. Supply Chain Management: An International Journal, 18 (3), 337-350.

Kardasz, H. (2008). Osiem skutecznych praktyk w zarządzaniu zakupami. Harvard Business Review Polska, May, 97-99.

Kraljic, P. (1983). Purchasing Must Become Supply Management. Harvard Business Review, 61 (5), 109-117.

Lockström, M. (2007). Low-cost country sourcing: Trends and implications. Wiesbaden: Springer Science \& Business Media \& Deutscher Universitäts-Verlag.

Lysons, K. (2004). Zakupy zaopatrzeniowe. Warszawa: PWE.

Lysons, K., Farrington, B. (2012). Purchasing and Supply Chain Management. Harlow: Pearson Education Ltd.

Monczka, R.M., Handfield, R.B., Giunipero, L.C., Patterson, J.L. (2009). Purchasing and supply chain management. USA: SouthWestern Cengage Learning.

Ocicka, B. (2017). Strategie zakupowe przedsiębiorstw w warunkach niestabilności. Handel Wewnętrzny, 3 (368), $335-336$.

Orlen (2018). Konsolidacja procesów zakupowych w grupie Orlen. Retrieved from: https://www.orlen.pl/PL/BiuroPrasowe/Strony/ KONSOLIDACJA-PROCESOW-ZAKUPOWYCH-W-GRUPIE-ORLEN.aspx.

Paranikas, P., Whiteford, G., Tevelson, B., Belz, D. (2015). How to Negotiate with Powerful Suppliers. Harvard Business Review, $93(7 / 8), 90-96$.

Rutkowski, K. (2013), Zakupy w biznesie - potrzeba strategicznej reorientacji. Kwartalnik Nauk o Przedsiębiorstwie, 4, 35-45.

Van Weele, A.J. (2005). Purchasing \& Supply Chain Management: Analysis, Strategy, Planning and Practice. London: Thomson International.

Van Weele, A.J. (2014). Purchasing \& Supply Chain Management: Analysis, Strategy, Planning and Practice. London: Thomson International.

Waters, D. (2003). Logistics. An introduction to supply chain logistics. New York: Palgrave Macmillan.

Cite this article aS: Drobiazgiewicz, J. (2018). Centralization of procurement - essence and current trends. European Journal of Service Management, 4 (28/1), 111-116. DOI: 10.18276/ejsm.2018.28/1-14. 